İşletme Akademisi Dergisi
2021,2 2(1): 25-39.
Dol:10.2677/TR1010.2021.699
Dergi web sayfasl: www.isakder.org

Araștırma Makalesi

\title{
Borsa İstanbul'da İşlem Gören Perakende Ticaret Şirketleri Hisse Senetlerinin Performansının Treynor Oranı ile Ölçümü
}

\author{
Prof. Dr. Ateş BAYAZIT HAYTA
}

Ankara Hacı Bayram Veli Üniversitesi, İktisadi ve İdari Bilimler Fakültesi, Uluslararası Ticaret Bölümü, Ankara, ates.hayta@hbv.edu.tr,www.orcid.org/0000-0002-5467-9288

\section{Öğr. Gör Turgay YAVUZARSLAN}

Ondokuz Mayıs Üniversitesi, Çarşamba Ticaret Borsası MYO, Muhasebe ve Vergi Uygulamaları Bölümü, Samsun, turgay.yavuzarslan@omu.edu.tr, www.orcid.org/0000-0002-0481-1279

\section{Öz}

Türkiye gibi gelişmekte olan bir ekonomide risksiz getirinin üzerinde getiri elde etmek isteyen bir yatırımcı için en önemli yatırım araçlarından biri hisse senedidir. Hisse senedine yatırım yaparak risksiz getiri alternatifinden vazgeçen yatırımcılar, almış olduğu riske karşlık risksiz getirinin üzerinde getiri beklemektedir. Buna göre yatırım yapılacak hisse senedinin tercihi son derece önem taşımaktadır. Hisse senedinin riskini, risksiz getiriyi ve hisse senedinin ortalama getirisini dikkate alan Treynor performans ölçümü yöntemi bu alanda kullanılabilecek önemli bir yöntemdir. Çalışmamızda Borsa İstanbul'da işlem gören perakende ticaret şirketlerinin hisse senetlerinin performansı geçmiş 5 yılın aylık getiriler üzerinden hesaplanan Treynor oranlarına göre ölçülmüştür. Elde edilen ölçüm sonuçları, 2019 yılı Eylül ve Ekim ayı gerçekleşen getirileri ile kıyaslanmıştır. Yalnızca dört hisse senedinin pozitif Treynor oranına sahip olduğu, risksiz getirinin üzerinde getiri sağladığı, diğerlerinin Treynor oranlarının negatif olduğu, risksiz getirinin altında getiri sağladıkları tespit edilmiştir. Pozitif Treynor oranına sahip hisse senetlerinin 2019 yılı Eylül ve Ekim ayı ortalama getirisinin, diğer hisse senetlerinden daha yüksek olduğu tespit edilmiştir.

Anahtar Kelimeler: Hisse Senedi Performansı, Treynor Oranı, Portföy Yönetimi.

Makale Gönderme Tarihi: 21.12.2020

Makale Kabul Tarihi: 09.02.2021

\section{Önerilen Atıf:}

Bayazıt Hayta, A. ve Yavuzaslan, T. (2021). Borsa İstanbul'da İşlem Gören Perakende Ticaret Şirketleri Hisse Senetlerinin Performansının Treynor Oranı ile Ölçümü, İ̧̧letme Akademisi Dergisi, 2(1): 25-39.

(C) 2021 İşletme Akademisi Dergisi. 


Journal of Business Academy
$2021,2(1): 25-39$.
Dol:10.26677/TR1010.2021.699
Web pages: www.isakder.org

Research Article

\title{
Measurement of The Performance of Stocks of Retail Trade Companies Traded on Borsa İstanbul With Treynor Ratio
}

\section{Prof. Dr. Ateş BAYAZIT HAYTA}

Ankara Hacı Bayram Veli University, Faculty of Economics and Administrative Sciences, Department of International Trade, Ankara, ates.hayta@hbv.edu.tr, www.orcid.org/0000-00025467-9288

\section{Lecturer Turgay YAVUZARSLAN}

Ondokuz Mayıs University, Çarşamba Commodity Exchange Vocational School, Department of Accounting and Tax Applications, Samsun, turgay.yavuzarslan@omu.edu.tr,

\section{www.orcid.org/0000-0002-0481-1279}

\begin{abstract}
Equity investment in developing countries is an important alternative to generating returns above risk-free returns. Investors who take risks by investing in stocks, expect returns above riskfree returns. Accordingly, the preference of the equity to be invested is extremely important. The Treynor performance measurement method, which takes into consideration the stock risk, riskfree return and average return of the stock, is an important method that can be used in this field. In our study, the performance of stocks of retail trade companies traded on Borsa Istanbul was measured according to Treynor ratios calculated over monthly returns of the past 5 years. The results of the measurements were compared with the results of September and October 2019. Only four stocks have positive Treynor ratios, yield higher than risk-free returns, others have negative Treynor ratios, yield less risk-free returns. Study shows that, stocks which have positive Treynor ratio generated higher return in September and October 2019 higher than other stocks.
\end{abstract}

Keywords: Equity Performance, Treynor Ratio, Portfolio Performance.

Received: 21.12 .2020

Accepted: 09.02.2021

\section{Suggested Citation:}

Bayazit Hayta, A. and Yavuzaslan, T. (2021). Measurement of The Performance of Stocks of Retail Trade Companies Traded on Borsa İstanbul With Treynor Ratio, Journal of Business Academy, 2(1): 25-39.

(C) 2021 Journal of Business Academy. 


\section{Gİkiş̧}

Finans piyasalarında yatırımcıların tercih edebileceği en önemli alternatiflerden biri hisse senedidir. Özellikle Türkiye gibi gelişmekte olan ekonomilerde genel olarak riskin yüksek olması nedeniyle, hisse senetleri piyasası, yatırımcılara yüksek getiri elde etme şansı vermektedir. Burada yatırımcıların amacı, alınacak riske karşılık en yüksek getiriyi elde etmektir. Buna göre, yatırımcıların riski ve beklenen getirilerini tespit etmeleri gerekmektedir. Hisse senedi piyasasında yatırımcların dikkate alacağı risk "sistematik risk" olarak ifade edilmektedir.

Sistematik risk, ekonomik, politik ve diğer çevre şartlarından kaynaklanan ve tüm şirketleri etkileyen, çeşitlendirmeyle yok edilemeyen riskleri ifade etmektedir (Aksoy ve Tanrı̈ven, 2007). Bahsedilen riskler, şirketlerin ve yatırımcıların kontrol edemeyeceği fakat kaçınılmaz olarak etkileneceği risklerdir. Burada yatırımcıların amacı riski iyi bir şekilde yönetmek olacaktır. Başarılı bir risk yönetimi ile alacakları riske karşılık en yüksek getiriyi elde edeceklerdir.

Riskin dışında diğer önemli husus yatırımcının beklenen getirisi olacaktır. Hisse senedine yatırım yapan bir yatırımcı risksiz sabit getiriden vazgeçmiş olacaktır. Birikimini finansal piyasalarda ödünç vererek faiz geliri elde eden bir yatırımcı neredeyse riskten tamamen korunmuş olacaktır. Ödünç verilen tarafın devlet olması durumunda ise teorik olarak yatırımcı riskten tamamen korunmuş olacaktır. Bununla birlikte bahsedilen yatırımı tercih eden yatırımcı için riskin ortadan kalkmasıyla birlikte fazladan getiri elde etme şansı da olmayacaktır. Diğer bir anlatımla, riskin ortadan kalkmasıyla getiri de sabitlenecektir. Hisse senedi yatırımını tercih eden bir yatırımcı için en önemli gösterge risksiz getiri oranı olacaktır. Hisse senedine yatırım yaparak sabit risksiz getiriden vazgeçen yatırımcı, almış olduğu riske karşılık risksiz getirinin üzerinde kazanç sağlamak isteyecektir. Aksi takdirde yapılan yatırım, verimsiz bir yatırım olacaktır.

Jack L. Treynor 1965 yılında, hisse senedi performansını, sistematik risk, risksiz getiri ve hisse senedi getirisini göz önünde bulundurarak ölçen bir yöntem geliştirmiştir. Buna göre öncelikle hisse senedinin riskini ifade eden Beta değeri hesaplanmakta, sonrasında hisse senedinin ortalama getirisiyle risksiz getiri arasındaki fark alınarak, hisse senedinin riskine göre sağladığ getiriye bakılarak performansı ölçülmektedir.

Çalışmamızda Borsa İstanbul'da işlem gören Perakende Ticaret Sektöründeki şirketlerin hisse senetlerinin son 5 yıllık, aylık getirileri üzerinden Treynor oranı ile performansları ölçülmüştür. Elde edilen veriler 2019 yılı Eylül ve Ekim ayında gerçekleşen getiriler ile karşılaştırılmış ve değerlendirmesi yapılmıştır.

\subsection{Hisse Senedi Performans1}

Yatırımların performansının ölçümü, yatırımcılar ve portföy yönetim şirketleri için büyük önem taşımaktadır. 1960'ların başlangıcında ortaya çıkan portföy teorisinin geliştirilmesinden sonra portföy performansının ölçümüne yönelik çalışmalar hız kazanmışır. Litaretürde bu konuyla ilgili oldukça fazla çalışma bulunmasına rağmen bunların çok azı yatırımların performansının ölçülmesinde esas olarak alınır. Bu temel çalışmalardan biri ilk kez bileşik bir portföy performans ölçümü yönteminin uygulandığı Treynor'un 1965 yılında yapmış olduğu çalışmadır (Alptekin, 2009).

Treynor endeksi betayı esas alan ve her bir birim ek risk için elde edilen ek getiriyi ölçen orandır (Samırkaş ve Düzakın, 2012). Hisse senedinin veya portföyün getirisi ile risksiz faiz oranı arasındaki fark, hisse senedinin veya portföyün risk primi olarak ifade edilmektedir. Hisse senedi veya portföyün karakteristik doğrusunun eğimi ise beta katsayısı ile ifade edilmektedir (Dağlı, Bank ve Er, 2008). Beta katsayısı piyasanın genel olarak maruz kalabileceği sistematik risklerin 
ölçüsü olarak kabul edilmektedir (Sarılı ve Yıldırtan, 2016). Sistematik risk, bütün yatırım araçlarının verimliliklerini etkileyen ekonomik, politik ve diğer çevre şartlarındaki değişmelerin getirdiği risklerdir. Enflasyona bağlı olarak paranın satın alma gücünde meydana gelen değişimler, piyasa faiz oranında meydana gelen değişimler, yatırım yapılan varlıkların piyasa fiyatında meydana gelen değişimler, politik durumlarda meydana gelen değişiklikler ve döviz kurunda meydana gelen değişimler, sistematik riskin parçası olarak yatıım yapılan varlıklardan elde edilen verimi etkileyen değişkenlerdir (Aksoy ve Tanriöven, 2007).

Sistematik riski ifade etmek için yararlanılan Beta katsayısı, herhangi bir hisse senedinin pazardaki dalgalanmalara karşı duyarlılığının bir ölçüsüdür. Bir başka deyişle, bir menkul kıymetin, portföyün getirisine ve riskine katkısı, bu menkul kıymetin beta katsayısı ile ölçülür. Beta katsayısı 1'in üzerinde olan hisse senetleri piyasadaki değişimleri duyarlılı̆̆ı yüksek hisse senetleri, 0 ile 1 arasında olanlar ise piyasa getirisine duyarlılığ 1 düşük hisse senetleridir. Negatif beta katsayısına sahip hisse senetleri ise piyasadaki değişimin tersine hareket eden hisse senetleridir (Ceylan ve Korkmaz, 1998).

Beta katsayısı, hisse senedi için risk ve getiri arasında ilişkiyi ve hisse senedinin getirisinin piyasa getirisine olan duyarlılığını göstermektedir (Tetik ve Uğur, 2010). Hisse senedi yatırımlarında risk ölçüsü olarak kullanılan beta katsayısı, hisse senedi ile piyasa getirisi arasındaki ilişkiyi ifade etmek için geçmiş getirilerden yararlanır (İskenderoğlu, 2012). Beta katsayısı muhtemel riskin tespiti için kullanılabileceği gibi gelecekteki getiri ve riskin tespiti için de kullanılabilir (Demir ve Kaderli, 2007).

Sistematik riskin göstergesi piyasa getirisine göre hisse senedinin getirisini gösteren karakteristik doğrunun eğimi olarak hesaplanacaktır. Buna göre Beta katsayısı aşağıdaki formül vasıtasıyla hesaplanabilir:

$\beta=\frac{\operatorname{Kovaryans}(R e, R m)}{\operatorname{Varyans}(R m)}$

Denklemde Re, hisse senedinin getirisini, $\mathrm{Rm}$ ise piyasa getirisini ifade etmektedir. Elde edilen değer, hisse senedinin getirisinin, piyasada getirisinden etkilenme derecesini ifade edecektir.

Ortalama getiri, risksiz getiri ve hisse senedinin Beta $(\beta)$ değerini dikkate alan Treynor oranı aşağıdaki formül aracalığıyla hesaplanmaktadır:

Treynor Oran $1=\frac{R i-R F}{\beta i}$

Formülde ifade edilen Ri hisse senedi veya portföyün ortalama getirisini, RF risksiz getiri oranını, $\beta_{i}$ ise hisse senedi veya portföyün beta değerini ifade etmektedir.

Finansal varlığın ya da portföyün betasının 1'den büyük olması piyasadan daha riskli, 1'den küçük olması ise piyasadan daha düşük riskli olduğunu göstermektedir (Güçlü, 2019).

Buradan hareketle beta katsayısı yatırımcılara piyasa beklentilerine göre hangi hisse senedini seçmeleri konusunda yol gösterecektir. Örneğin, Borsa İstanbul'da endeksin yükselmesini bekleyen bir yatırımcı piyasadaki getirinin üzerinde bir getiri sağlayacağından beta katsayısı 1'in üzerinde olan bir hisse senedi seçmelidir. Endekste düşüş bekleyen bir yatırımcı ise piyasanın tersi yönde hareket edeceğinden beta katsayısı negatif olan bir hisse senedi seçmelidir. Bununla beraber yatırımcilar "risk ve getiri doğru orantılıdır" prensibine uygun olarak bu hisse senetlerine yaptıkları yatırımla gelir beklentilerine bağlı olarak üstlendikleri riski de artırmaktadırlar.

Elde edilmesi beklenen getiri oranı aynı olan iki yatırımdan, daha düşük riskli olan yatırımcılar tarafından tercih edilmektedir. Risk seviyesi aynı olan yatırımlar arasından ise daha yüksek 
getirili olanlar tercih edilmektedir. Bu şekilde yatırımdan sağlanacak faydayı en yüksek seviyeye çıkarmak için yatırımcı riskten kaçarak düşük getiriyi kabul edecek veya alacağı riskle beraber daha yüksek getiri elde etmeyi bekleyecektir (Çalışkan, 2011).

Treynor Endeksi yöntemi aynı beta değerine sahip olan hisse senetlerinden daha yüksek getiriye sahip olanını seçilmesi gerektiğini ifade eder. Bir başka anlatımla, Treynor oranı yüksek olan hisse senedi en iyi performansı gösteren hisse senedidir (Sevinç ve Yakar, 2019).

\section{2. İlgili Araştırmalar}

Son yıllarda Türkiye'de performans ölçümünde Treynor oranından yararlanılarak yapılan çalışmalar aşağıda kısaca sunulmuştur.

Samırkaş ve Düzakın (2012) tarafından yapılan çalışmada 2000 ve 2010 yılları arasında Türkiye'deki A ve B tipi fonların performans ölçümü Treynor, Sharpe ve Jensen yöntemleriyle gerçekleştirilmiştir. Çalışma sonucunda üç yöntemde de A tipi fonların daha başarılı olduğu sonucuna ulaşılmıştır.

Sarılı ve Yıldırtan (2016) tarafından yapılan çalışmada İslami Endekslerin getirileri Sharpe, Treynor ve Jensen oranlarıyla karşılaştırmalı olarak incelenmiştir. En iyi performansı S\&P İslami endeksinin, en kötü performansı ise FTSE'nin ise en düşük performansı gösterdiği sonucuna ulaşılmıştır.

İpekten vd., (2020) tarafından yapılan çalışmada 2013-2017 yılları arasında Türkiye'de 30 adet yatırım fonunun performansı Sharpe, Treynor ve Jensen oranlarıyla ölçülmüştür. Araştırma sonucunda Treynor indeksi yöntemine göre A tipi hisse senedi fonları başarılı, A tipi altın fonları ise başarısız olarak bulunmuştur.

Arslan ve Çelik (2018) tarafından yapılan çalışmada Emeklilik yatırım fonlarının performansı ile BİST 100 endeksinin performansı Sharpe, Treynor ve Jensen oranlarıyla karşılaştırmalı olarak ölçülmüştür. 2014-2017 yıllarını kapsayan çalışmada 157 adet emeklilik fonu incelenmiştir. Çalışma sonuçlarına göre Sharpe oranını göre 48 adet emeklilik fonu, Treynor oranına göre 21 emeklilik fonu, Jensen oranına göre 51 emeklilik fonu BİST 100 endeksinden daha iyi performans göstermiştir.

Ayaydın (2013) tarafından yapılan çalışmada 2010-2013 döneminde Türkiye' deki 34 ade esnek ve dengeli emeklilik yatırım fonunun performansı Sharpe, Treynor ve Jensen oranlarıyla ölçülmüştür. Çalışma sonuçlarını genel olarak esnek ve dengeli yatırım fonlarının performansı başarısız bulunmuş, piyasa getirisinin altında getiri sağladıkları sonucuna ulaşılmıştır.

Dağlı vd., (2008) yapmış oldukları çalışmada Türkiye' de ki bireysel emeklilik yatırım fonlarının performansını Sharpe, Treynor ve Jensen oranlarıyla ölçmüşlerdir. 2003-2007 dönemi için 10 adet emeklilik fonu incelenmiştir. Çalışma sonucunda bireysel emeklilik yatırım fonlarının piyasa getirisinin altında getiri sağladıkları tespit edilmiştir.

Özer ve Çömlekçi (2020) tarafından yapılan çalışmada odaklanma stratejisi izleyen fonlar ile çeşitlendirme stratejisi izleyen fonların performansı Sharpe, Treynor ve Jensen oranları kullanılarak 2013-2020 dönemi için karşılaştırmalı olarak incelenmiştir. Çalışma sonucunda odaklanma stratejisi ile oluşturulan portföyün çeşitlendirme stratejisi ile oluşturulan portföyden daha iyi performans gösterdiği tespit edilmiş, ayrıca teknoloji odaklı portföyün en yüksek getiriyi sağladığı tespit edilmiştir.

Sevinç ve Yakar (2019) tarafından yapılan çalışmada 2014-2018 dönemi için Türkiye' deki 28 hisse senedi yatırım fonunun performansı Sharpe, Treynor ve Jensen yöntemlerine göre ölçülmüştür. 
Çalışma sonuçlarını göre incelenen fonların birçoğunun piyasa getirisine göre başarılı olduğu tespit edilmiştir.

Sönmezler (2021) tarafından yapılan çalışmada Covid 19 salgınının BİST 30 hisse senetlerinin performansına etkileri CAPM, aritmetik getiriler, Sharpe, Treynor ve Sortino oranları ile hesaplanmıştır. Çalışma sonucuna göre sanayi ve perakende sektöründe yer alan hisse senetlerinin incelenen dönemde riske göre sağladığı getiriye göre daha başarılı oldukları, havayolu ve banka hisselerinin ise daha başarısız olduğu tespit edilmiştir.

Oran vd., (2017) yılında yapılan çalışmada Türkiye'de A tipi yatırım fonları ile emeklilik yatırım fonlarının performansı ölçülmüştür. 2009-2015 yılları arasında Sharpe, Sortino, Treynor ve Jensen oranları kullanılarak gerçekleştirilen çalışmada, incelenen fon yöneticilerinin piyasa getirisinin üzerinden getiri sağlamada genel olarak başarısız oldukları tespit edilmiştir. Genel olarak yatırım fonlarının emeklilik fonlarından daha iyi performans gösterdikleri sonucuna ulaşılmıştır.

Uysal ve Adalı (2018) yapmış oldukları çalışmada geleneksel emeklilik yatırım fonları ile İslami emeklilik yatırım fonlarının performansını karşılaştırmalı olarak analiz etmiştir. Çalışma sonuçlarına göre her iki tip fonun yöneticileri de başarılı olarak değerlendirilmiş, geleneksel emeklilik fonlarının performansının daha iyi olduğu tespit edilmiştir.

Alkan ve Kuşaksızoğlu (2017) yapmış oldukları çalışmada 2013-2016 döneminde Türkiye'de en büyük 10 yatırım fonunun getiriye dayalı performansını Sharpe, Treynor ve Sortino oranlarına göre ölçmüş ve başarılarına göre sıralamışlardır.

Kök ve Erikçi (2015) A tipi yatırım fonlarının performansını 2004-2013 dönemi için araştırmışlardır. Çalışma sonuçlarına göre endeks fonların piyasadaki dalgalanmalara karşı daha hassas oldukları, karma fonların ise daha dayanıklı oldukları tespit edilmiştir.

Görüldügü üzere literatürdeki araştırmalar genel olarak portföylerin performans ölçümlerine odaklanmış ve performans ölçümünde birden fazla orandan yararlanılmıştır. Sistematik riski göz önünde bulundurması, yatırımın risksiz getiriye göre sağladığı getiriyi ölçü olarak alması ve hisse senedinin bireysel performans analizini yapmaya tarafımızca daha elverişli görülmesi nedenleriyle, çalışmamızda Treynor oranından yararlanılmıştır.

\section{YÖNTEM}

\section{1. Çalışma Grubu}

Perakende sektöründeki 11 işletmenin hisse senetleri için 1 Eylül 2014-31 Ağustos 2019 dönemindeki aylık getirileri dikkate alınarak beta, ortalama getiri ve Treynor oranı değerleri hesaplanmıştır. Mavi Giyim Sanayi ve Ticaret A.Ş. için 2017 yılı temmuz ayı, Şok Marketler Ticaret A.Ş. için ise 2018 yılı haziran ayı söz konusu tarihlerde hisselerinin borsada işlem görmeye başlaması nedeniyle analizlerin başlangıç noktası seçilmiştir. Elde edilen veriler sonucunda incelenen hisse senetlerinin 2019 yılı Eylül ve Ekim ayı gerçekleşen getirileri karşılaştırılmıştır.

Hisse senetleri Borsa İstanbul'da işlem görmekte olan 11 adet perakende ticaret işletmesinin şirket ünvanları ve borsadaki hisse senedi kodları aşağıdaki gibidir: 
Tablo 1. Borsa İstanbul'da Hisse Senetleri İşlem Gören Perakende Ticaret Şirketleri

\begin{tabular}{lll}
\hline Sıra & Kod & Şirket Unvanı \\
\hline 1 & ADESE & ADESE ALIŞVERIŞ MERKEZLERİ TICARET A.Ş. \\
2 & BIMAS & BİM BİRLEŞIK MAĞAZALAR A.Ş. \\
3 & BIZIM & BİZIM TOPTAN SATIŞ MAĞAZALARI A.Ş. \\
4 & CRFSA & CARREFOURSA CARREFOUR SABANCI TICARET MERKEZİ A.Ş. \\
5 & MAVI & MAVİ GIYIIM SANAYİ VE TİCARET A.Ş. \\
6 & MEPET & MEPET METRO PETROL VE TESİSLERİ SANAYİ TİCARET A.Ş. \\
7 & MGROS & MİGROS TİCARET A.Ş. \\
8 & MIPAZ & MİPA TİCARİ VE SINAİ ÜRÜNLER PAZ SAN. VE TİC. A.Ş. \\
9 & SOKM & ŞOK MARKETLER TICARET A.Ş. \\
10 & TKNSA & TEKNOSA İÇ VE DIŞ TİCARET A.Ş. \\
11 & VAKKO & VAKKO TEKSTILL VE HAZIR GIYIM SANAYİ İŞLETMELERİ A.Ş. \\
\hline
\end{tabular}

\subsection{Verilerin Toplanması ve Analizi}

Araştırmada Borsa İstanbul'da ortaya çıkan hisse senedi fiyatlarının verilerinden yararlanılmıştır. Veri analizinde Treynor İndeksi yöntemi kullanılmıştır. Treynor indeksi yöntemi, alınan bir birim risk için ne kadar getiri elde edileceğini belirleyen yöntemdir. Yöntemde risksiz getirinin üzerinde getiri elde edilmesi beklenir. Bu yüzden hesaplamada risksiz getiri oranı dikkate alınır. Araştırmada risksiz faiz oranı olarak Türkiye Cumhuriyet Merkez Bankası' nın 12 Eylül 2019 tarihi itibariyle uyguladığı yıllık faiz oranı olan \%16,5 esas alınmıştır. Yıllık risksiz getiri oranının aylık risksiz getiri oranına dönüşümü için aşağıdaki formülden yararlanılmıştır:

Aylık Faiz Oranı $=\left(\left(1+Y_{1} 1 l ı k \text { Faiz Oranı }\right)^{\wedge}(1 / 12)\right)-1$

Buna göre;

Aylık Faiz Oranı $=\left((1+0,165)^{\wedge}(1 / 12)\right)-1$

Aylık Faiz Oranı $=0,01280809$

Çalışmada aylık getiriler esas alındığından yukarıda hesaplanan aylık risksiz getiri oranı \%1,280809 kullanılmıştır.

Treynor oranının hesaplaması hisse senedi veya portföyün betası üzerinden yapılır. Beta katsayısı hisse senedi veya portföyün oynaklığını yani riskini gösterir ve piyasa üzerinden hesaplanır. Çalışmada her bir hissenin betası, BİST 100 endeksi üzerinden hesaplanmıştır. 1 Eylül 2014-31 Ağustos 2019 zaman serisi içinde her bir hisse senedinin aylık getiri bağımlı değişken, BIST 100 endeksinin aylık getirisi bağımsız değişken alınarak her bir hisse senedinin beta değeri hesaplanmıştır. Söz konusu dönem için hisse nedenin ortalama getiri ile risksiz faiz oranı arasındaki fark, hisse senedi beta değerine bölünerek her bir hisse senedi için Treynor oranı belirlenmiştir. Yönteme göre Treynor oranı en yüksek olan hisse senedi performansı en yüksek hisse senedi olarak kabul edilmektedir. Verilerin analizi excel programı üzerinde yapılmıştır.

\section{BULGULAR}

\subsection{Perakende Sektörü Hisse Senetlerinin Analizi}

İncelenen hisse senetlerinin 1 Ekim 2014-30 Eylül 2019 dönemindeki (Mavi A.Ş. için 2017 yılı Temmuz ayı, Şok A.Ş. için 2018 yılı Haziran ayı başlangıç noktası esas alınmıştır.) aylık getirileri dikkate alınarak hesaplanan beta değerleri aşağıdaki gibidir: 
Tablo 2. Hisse Senetlerinin Beta Değerleri

\begin{tabular}{ll}
\hline Hisse Senedi & Beta Değeri \\
\hline ADESE & 0,536750033 \\
BİM & 0,67199654 \\
CARREFOURSA & 0,78139303 \\
BİIIM & 0,81192519 \\
VAKKO & 0,983446229 \\
MİLPA & 1,032711307 \\
MİGROS & 1,085237997 \\
ŞOK & 1,112967884 \\
TEKNOSA & 1,177733516 \\
MEPET & 1,247131228 \\
MAVI & 1,489044834 \\
\hline
\end{tabular}

Hisse senetlerinin beta değeri, söz konusu hissenin riskini tespit etmek için yararlanılan bir değerdir. Genel olarak beta değeri 1'in üzerinde olan hisse senetleri riskli, 1'in altında olanlar düşük riskli olarak kabul edilir. Bu noktada finansın temel ilkelerinden "risk ve getiri doğru orantılıdır" kavramı ile karşılaşılmaktadır. Beta değeri 1'in altında olan hisse senetlerinin riski düşük olduğu için getirilerinin de düşük olması beklenmektedir. 1'in üstünde beta değerine sahip olan hisse senetlerinin de riskinin yüksek olması nedeniyle getirisinin de yüksek olması beklenmektedir.

Araştırmaya konu işletmeler dikkate alındığında 5 işletmenin hisse senetlerinin beta değerinin 1 'in altında olduğu ve düşük riskli olarak sınıflandırılabileceği, 6 işletmenin ise hisse senetlerinin beta değerinin $1^{\prime}$ in üzerinde olduğu ve riskli hisse senedi olarak sinfflandırılabileceği görülmektedir. En düşük beta değerine sahip hisse senedinin ADESE Alışveriş Merkezleri Ticaret A.Ş.'ye, en yüksek beta değerine sahip hisse senedinin ise Mavi Giyim Sanayi ve Ticaret A.Ş.'ye ait olduğu olduğu tespit edilmiştir.

Hisse senetlerinin incelenen dönemler için ortalama getirileri ile risksiz getirileri ve aralarındaki farklar aşağıdaki gibidir:

Tablo 3. Hisse Senetlerinin Risk Pirimleri

\begin{tabular}{llll}
\hline Şirket Unvanı & Ortalama Getiri & Risksiz Getiri & Fark \\
\hline VAKKO & 2,7122 & 1,2808 & 1,4314 \\
MILPA & 1,8238 & 1,2808 & 0,5430 \\
ADESE & 1,6772 & 1,2808 & 0,3964 \\
BİM & 1,3040 & 1,2808 & 0,0232 \\
ŞOK & 0,9873 & 1,2808 & $-0,2935$ \\
CARREFOURSA & 0,9685 & 1,2808 & $-0,3123$ \\
MAVI & 0,7382 & 1,2808 & $-0,5426$ \\
MİGROS & 0,0922 & 1,2808 & $-1,1886$ \\
BİZIM & $-0,5812$ & 1,2808 & $-1,8620$ \\
MEPET & $-1,2966$ & 1,2808 & $-2,5774$ \\
TEKNOSA & $-2,0184$ & 1,2808 & $-3,2992$ \\
\hline
\end{tabular}


İncelenen dönemler itibariyle hisse senetlerinin sağladığı ortalama getiri ile risksiz getiri arasındaki fark incelendiğinde en yüksek aylık getiri Vakko A.Ş. hisse senedinden sağlanmaktadır. Ardından Milpa, Adese ve Bim A.Ş. hisse senetleri gelmektedir. Bu işletmelerin hisse senetleri risksiz getirinin üzerinde aylık ortalama getiri sağlamaktadır. ŞOK, Carrefoursa, Mavi ve Migros hisse senetleri ise risksiz getiriden daha düşük aylık ortalama getiri sağlamaktadır. Bizim, Mepet ve Teknosa A.Ş. hisse senetlerinin ise incelenen dönemler itibariyle aylık ortalama getirileri negatif (zarar) durumdadır.

Sözkonusu işletme hisse senetlerinin Treynor oranları aşağıdaki gibidir:

Tablo 4. Hisse Senetlerinin Treynor Oranları

\begin{tabular}{ll}
\hline Şirket Unvanı & Treynor Oranı \\
\hline VAKKO. & 1,455527826 \\
ADESE & 0,738567208 \\
MİLPA & 0,525764751 \\
BİM & 0,034558324 \\
ŞOK & $-0,263687589$ \\
MAVİ & $-0,36441928$ \\
CARREFOURSA & $-0,399670404$ \\
MİGROS & $-1,095257841$ \\
MEPET & $-2,066642327$ \\
BİIM & $-2,293337147$ \\
TEKNOSA & $-2,801335349$
\end{tabular}

İncelenen işletmelerin hisse senetlerinin Treynor oranlarına bakıldığında en yüksek oranın Vakko A.Ş. hisse senedine ait olduğu görülmektedir. Buna göre Treynor performans ölçüsünde geçmiş verilere göre en iyi performansı Vakko A.Ş. hisse senedi göstermiştir. Bu işletmeyi Adese, Milpa ve BİM hisse senetleri sırasıyla takip etmektedir. İncelenen işletmelerden Mavi, Şok, Carrefour ve Migros A.Ş.'lerin hisse senetlerinin aylık ortalama getirilerinin risksiz getirinin altında olması, Mepet, Teknosa ve Bizim A.Ş.'lerin ise aylık ortalama getirilerinin negatif olması nedeniyle Treynor oranları negatif çıkmıştır. Görüldüğü üzere Treynor oranı negatif çıkan hisse senetleri, risksiz getirinin altında kazanç sunduğu için yatırımcılar tarafından tercih edilmemesi gereken hisse senetleridir.

\subsubsection{Eylül 2019 Dönemi Gerçekleşen Getiriler}

İncelenen hisse senetlerinin ve BİST 100 endeksinin 2 Eylül 2019 Pazartesi açlış fiyatı ile 30 Eylül Pazartesi kapanış fiyatlarına göre gerçekleşen getirileri aşă̆ıdaki gibidir.

Tablo incelendiğinde, öncelikle BIST 100 endeksinin 2019 yılı Eylül ayında \%8,58 değer kazandığı görülmektedir. Bununla beraber incelenen hisse senetlerinin tamamı da Eylül ayında değer kazanmıştır. Hisse senetleri içinde en yüksek kazancı \%59,86 oranıyla ADESE A.Ş. hisse senedi sağlamıştır. ADESE, TEKNOSA, MAVİ, MEPET, MIGROS, MILPA ve CARREFOURSA A.Ş. hisse senetleri BIST 100 endeksinde meydana gelen artışın üzerinde getiri sağlamışlardır. VAKKO, BİZIM, BİM ve ŞOK A.Ş. hisse senetlerinin getirileri ise endeksteki artış oranının altında gerçekleşmiştir. Bununla birlikte hisse senetlerinin tamamı Eylül ayında aylık risksiz getiri oranının $(\% 1,28)$ üzerinde getiri sağlamıştır. 
Tablo 5. Hisse Senetlerinin Eylül-2019 Dönemi Getirileri

\begin{tabular}{|c|c|c|c|c|}
\hline \multirow[b]{2}{*}{ HİSSE SENEDİ } & \multirow[b]{2}{*}{$\begin{array}{l}\text { Açılış } \\
\text { Fiyatı }\end{array}$} & \multirow[b]{2}{*}{$\begin{array}{l}\text { Kapanış } \\
\text { Fiyatı }\end{array}$} & \multicolumn{2}{|l|}{ Fark } \\
\hline & & & Tutar & $\%$ \\
\hline ADESE & 1,47 & 2,35 & 0,88 & 59,86 \\
\hline TEKNOSA & 2,15 & 2,84 & 0,69 & 32,09 \\
\hline MAVİ & 37,14 & 46,14 & 9 & 24,23 \\
\hline MEPET & 1,21 & 1,39 & 0,18 & 14,88 \\
\hline MİGROS & 18,5 & 20,76 & 2,26 & 12,22 \\
\hline MİLPA & 1,59 & 1,77 & 0,18 & 11,32 \\
\hline CARREFOURSA & 3,3 & 3,66 & 0,36 & 10,91 \\
\hline VAKKO & 3,62 & 3,93 & 0,31 & 8,56 \\
\hline BİZIM & 8 & 8,6 & 0,6 & 7,50 \\
\hline BİM & 46,94 & 49,12 & 2,18 & 4,64 \\
\hline ŞOK & 10,56 & 11 & 0,44 & 4,17 \\
\hline BİST 100 & 96738 & 105033 & 8295 & 8,58 \\
\hline
\end{tabular}

\subsubsection{Ekim 2019 Dönemi Gerçekleşen Getiriler}

İncelenen hisse senetlerinin ve BIST 100 endeksinin 1 Ekim 2019 Salı açılış fiyatı ile 31 Ekim Perşembe kapanış fiyatlarına göre gerçekleşen getirileri aşağıdaki gibidir:

Tablo 6. Hisse Senetlerinin Ekim-2019 Dönemi Getirileri

\begin{tabular}{lllll}
\hline HİSSE SENEDİ & Açılış Fiyatı & Kapanış Fiyatı & Fark \\
& & & Tutar & $\%$ \\
\hline MEPET & 1,4 & 1,83 & 0,43 & 30,71 \\
MİLPA & 1,77 & 1,98 & 0,21 & 11,86 \\
MAVİ & 46,14 & 46,16 & 0,02 & 0,04 \\
MİGROS & 20,8 & 20,52 & $-0,28$ & $-1,35$ \\
VAKKO & 3,96 & 3,88 & $-0,08$ & $-2,02$ \\
BİZIM & 8,61 & 8,4 & $-0,21$ & $-2,44$ \\
BİM & 49,2 & 47,32 & $-1,88$ & $-3,82$ \\
CARREFOURSA & 3,68 & 3,42 & $-0,26$ & $-7,07$ \\
TEKNOSA & 2,85 & 2,63 & $-0,22$ & $-7,72$ \\
ADESE & 2,36 & 1,94 & $-0,42$ & $-17,80$ \\
ŞOK & 11,05 & 8,89 & $-2,16$ & $-19,55$ \\
BİST 100 & 105275 & 98468,52 & -6806 & $-6,47$ \\
\hline
\end{tabular}

2019 yılı Ekim ayında BİST 100 endeksinin \%6,47 oranında değer kaybettiği görülmektedir. Bu değer azalışıla birlikte MEPET, MILPA ve MAVİ A.Ş. hisse senetleri dışındaki tüm işletmelerin hisse senetleri değer kaybetmiştir. MEPET A.Ş. hisse senedi \%30,71 oranında, MILPA A.Ş. hisse senedi \%11,86, MAVI A.Ş. hisse senedi ise \%0,04 oranında değer kazanarak endeksin tersi yönünde hareket etmişlerdir. MIGROS, VAKKO, BİZIM ve BİM A.Ş. hisse senetleri endekste 
meydana gelen düşüşün altında değer kaybetmişlerdir. CARREFOUR, TEKNOSA, ADESE ve ŞOK A.Ş. hisse senetleri ise endeksten daha fazla değer kaybetmişlerdir.

\subsubsection{Gerçekleşen Getiriler, Treynor Oranlanı ve Beta Değerleri}

2019 yılı Eylül ve Ekim ayında gerçekleşen getiriler ve 2014 yılı Eylül ayı ile 2019 yılı Ağustos ayı arasındaki aylık getiriler esas alınarak hesaplanan Treynor oranları ve hisse senetlerinin Treynor oranı sıralamaları ile beta değerleri aşağıdaki gibidir:

Tablo 7. Hisse Senetlerinin Getiri Oranları, Treynor Oranları ve Beta Değerleri

\begin{tabular}{|c|c|c|c|c|c|c|c|c|}
\hline \multirow[b]{2}{*}{ Hisse Senedi } & \multicolumn{4}{|c|}{ Getiri Oranı } & \multicolumn{2}{|c|}{ Treynor } & \multicolumn{2}{|l|}{ Beta } \\
\hline & Eylül & Ekim & Toplam & Ortalama & Oranı & Sirası & Değeri & Sirasi \\
\hline MEPET & 14,88 & 30,71 & 45,59 & 22,80 & $-2,07$ & 9 & 1,25 & 10 \\
\hline ADESE & 59,86 & $-17,80$ & 42,07 & 21,03 & 0,74 & 2 & 0,54 & 1 \\
\hline TEKNOSA & 32,09 & $-7,72$ & 24,37 & 12,19 & $-2,80$ & 11 & 1,18 & 9 \\
\hline MAVİ & 24,23 & 0,04 & 24,28 & 12,14 & $-0,36$ & 6 & 1,49 & 11 \\
\hline MILPA & 11,32 & 11,86 & 23,19 & 11,59 & 0,53 & 3 & 1,03 & 6 \\
\hline MİGROS & 12,22 & $-1,35$ & 10,87 & 5,44 & $-1,10$ & 8 & 1,09 & 7 \\
\hline VAKKO & 8,56 & $-2,02$ & 6,54 & 3,27 & 1,46 & 1 & 0,98 & 5 \\
\hline BİZİM & 7,50 & $-2,44$ & 5,06 & 2,53 & $-2,29$ & 10 & 0,81 & 4 \\
\hline CARREFOURSA & 10,91 & $-7,07$ & 3,84 & 1,92 & $-0,40$ & 7 & 0,78 & 3 \\
\hline BİM & 4,64 & $-3,82$ & 0,82 & 0,41 & 0,03 & 4 & 0,67 & 2 \\
\hline ŞOK & 4,17 & $-19,55$ & $-15,38$ & $-7,69$ & $-0,26$ & 5 & 1,11 & 8 \\
\hline BİST 100 & 8,58 & $-6,47$ & 2,11 & 1,05 & - & - & - & - \\
\hline
\end{tabular}

Geçmiş verilerden elde edilen hisse senetlerinin Treynor oranları ile beta değerlerinin, Eylül ve Ekim ayları getirileri ile 2 aylık ortalama getirilerinin sonuçları toplu olarak değerlendirildiğinde, en yüksek getiriyi Mepet A.Ş. hisse senedinin sağladığı görülmektedir. Söz konusu hisse senedinin Treynor oranı incelenen 11 hisse senedi arasında 9. sırada, beta değeri ise 10. sıradadır. Buna göre geçmiş veriler değerlendirildiğinde, performansı düşük ve riski yüksek (beta değeri yüksek) hisse senedi en yüksek getiriyi sağlamıştır. Aynı zamanda Treynor oranının negatif olması, geçmiş verilere göre risksiz getirinin altında ortalama getiri sağladığını göstermektedir.

Eylül ve Ekim ayları ortalamasında en yüksek ikinci getiriyi sağlayan hisse senedi ise ADESE A.Ş. hisse senedi olmuştur. Hisse senedi Treynor performans ölçümü ile değerlendirildiğinde, 11 hisse senedi arasında ikinci hisse senedidir. Risk açısından değerlendirildiğinde ise beta değeri en düşük (riski düşük) hisse senedidir. Aynı zamanda hisse senedinin Treynor oranı pozitiftir. Buna göre geçmiş verilerde aylık getirisi risksiz getirinin üzeridedir.

İki aylık ortalama getiride en yüksek getiriyi sağlayan üçüncü hisse senedi Teknosa A.Ş.'ye aittir. Söz konusu hisse senedinin Treynor oranı değerlendirildiğinde 11 hisse senedi arasında en kötü performansı gösteren hisse senedi olduğu görülmektedir. Beta değeri açısından değerlendirildiğinde ise 11 hisse senedi arasında 9. sırada olduğu, riskinin yüksek olduğu görülmektedir.

Mavi A.Ş. hisse senedi iki aylık ortalama getiride $\% 12,14$ getiri sağlamış ve en yüksek getiriyi sağlayan dördüncü hisse senedi olmuştur. Treynor performans ölçümünde ise hisse senedinin 
performansı incelenen hisse senetleri arasında 6. sıradadır. Beta değeri incelendiğinde ise riski en yüksek hisse senedi olduğu görülmektedir.

Teknosa A.Ş. ve Mavi A.Ş. hisse senetlerinin Treynor oranları negatif olup, risksiz getirinin altında getiri sağlamışlardır.

Treynor performans ölçüsünde 3. sırada yer alan Milpa A.Ş. hisse senedi, Eylül ve Ekim ayı getirilerinde en yüksek getiriyi sağlayan 5 . hisse senedidir. Risk açısından değerlendirme yapıldığında 11 hisse senedi arasında 6. sırada olduğu görülmektedir. Hisse senedi geçmiş verilerde risksiz getirinin üzerinde aylık ortalama getiri sağladığı için Treynor oranı pozitiftir.

Eylül ve Ekim ayı getirilerinde altıncı sırada yer alan Migros hisse senedi, Treynor performans ölçümünde sekizinci, risk ölçümünde beta değerine göre altıncı sıradadır. Geçmiş 5 yılın verilerinde hisse senedi risksiz getirinin altında aylık getiri sağlamıştır.

En yüksek Treynor oranına sahip olan Vakko A.Ş. hisse senedi, Eylül ve Ekim ayı getirilerinde 7. sıradadır. Vakko A.Ş. hisse senedi risk açısından değerlendirildiğinde ise hisse senetleri arasında beşincidir. Yine geçmiş veriler değerlendirildiğinde hisse senedinin risksiz getirinin üzerinde aylık getiri sağladığı görülmektedir.

Treynor oranında en kötü ikinci performansa sahip Bizim A.Ş. hisse senedi, risk açısından ise en az riske sahip dördüncü hisse senedidir. Eylül ve Ekim ayı getirilerinde ise en az getiriyi sağlayan dördüncü hisse senedidir.

Beta katsayısına göre riski en düşük üçüncü hisse senedi olan Carrefoursa A.Ş. hisse senedi, Treynor oranında performansı ölçüldügüunde yedinci sıradadır ve incelenen hisse senetleri arasında Eylül ve Ekim aylarında en az getiriyi sağlayan üçüncü hisse senedidir.

Bizim ve Carrefoursa A.Ş. hisse senetleri için negatif Treynor oranları hesaplanmış olup, risksiz getirinin altında aylık getiri sağladıkları tespit edilmiştir.

Riski en düşük ikinci ve Treynor oranında performansı en yüksek dördüncü hisse senedi olan BİM A.Ş. hisse senedi Eylül ve Ekim aylarında en az getiriyi sağlayan ikinci hisse senedi olmuştur. Buna karşılık hisse senedinin Treynor oranı pozitiftir.

Eylül ve Ekim aylarında en kötü performansı gösteren hisse senedi iki ayda toplam \%15,38 değer kaybeden ŞOK A.Ş. hisse senedi olmuştur. Aynı hisse senedi negatif Treynor oranına sahip olmakla birlikte sıralamada beşinci sırada yer almaktadır. Risk açısından değerlendirildiğinde ise en düşük riskli sekizinci hisse senedi olduğu görülmektedir.

BIST 100 endeksinin yükseldiği Eylül ayı ve endeksin düştüğü Ekim ayı için söz konusu hisse senetlerinin performansı genel olarak değerlendirildiğinde hisse senedi performansı ile Treynor oranı arasında doğrudan bir ilişki kurmak mümkün görülmemektedir. Treynor oranı pozitif olan hisse senetlerine (Vakko, Adese, Milpa, Bim) Eylül ayı başında eşit oranlarda yatırım yapan bir yatırımcı Eylül ayında \%21,09 getiri elde etmiş, Ekim ayında \%2,95 zarar etmiş, iki aylık toplamda $\% 18,15$, aylık ortalamada \%9,07 kar elde etmiş olacaktır. Aynı tarihte negatif Treynor oranına sahip hisse senetlerine (Mepet, Teknosa, Mavi, Migros, Bizim, Carrefoursa, Şok) eşit oranlarda yatırım yapan bir yatırımcı Eylül ayında \%15,14 getiri elde etmiş, Ekim ayında \%1,05 zarar etmiş, iki aylık toplamda $\% 14,09$, aylık ortalamada $\% 7,04$ getiri elde etmiş olacaktır. Buna göre pozitif Treynor oranına sahip olan, yatırım yapılabilir olarak görülen hisse senetleri Eylül ayında, negatif Treynor oranına sahip hisse senetlerinden daha yüksek getiri elde edecektir. Endeksin düştüğ̈̈ Ekim ayında ise pozitif Treynor oranına sahip hisse senetlerinin, negatif Treynor oranlı hisse senetlerinden daha fazla zarar ettirdiği görülmektedir. Buna karşılık iki aylık toplam ve ortalama getiriler dikkate alındığında pozitif Treynor oranına sahip hisse senetlerinin daha çok kazandırdığı görülmektedir. 


\section{SONUÇ ve ÖNERILER}

Hisse senedi yatırımı, riskli piyasalara sahip olması nedeniyle Türkiye gibi gelişmekte olan ülkelerde yatırımcılara yüksek kazançlar elde etme imkanı sunan önemli bir yatırım alternatifidir. Hisse senedine yatırım yaparak risk alan yatırımcılar, risksiz getirinin üzerinde kazanç sağlayarak, almış oldukları riskin karşılığını almak isteyeceklerdir. Getirisi önceden belirlenmiş, risksiz, hazine bonosu gibi yatırım araçları yerine hisse senedine yatırım yapan bir yatırımcının yaptığı yatırımın, verimli bir yatırım olabilmesi için risksiz getirinin üzerinde getiri sağlaması gereklidir. Bunun için yatırımcının riski ve risksiz getiriyi göz önünde bulundurarak yatırım tercihi yapması son derece önemlidir.

Jack L. Treynor tarafından geliştirilen performans ölçüsü, hisse senedinin performansını belirlemek için yukarıda bahsedilen değişkenleri göz önünde bulunduran birleşik bir performans ölçüm yöntemidir. Söz konusu yöntem, sistematik riski ( $\beta$ katsayısı), risksiz getiriyi ve hisse senedinin ortalama getirisini dikkate almaktadır. Buna bağlı olarak yatırımcının almış olduğu riske göre elde edeceği getiri üzerinden hisse senedinin performansı ölçülmektedir.

Çalışmamızda geçmiş 5 yıllık veriler üzerinden Treynor performans ölçümü yöntemine göre Borsa İstanbul' da faaliyet gösteren perakende ticaret şirketlerinin hisse senetlerinin performansı ölçülmüş, elde edilen değerler, 2019 yılı Eylül ve Ekim aylarında gerçekleşen getiriler ile karşılaştırılmıştır.

Geçmiş veriler üzerinden öncelikle hisse senetlerinin sistematik riske karşılık duyarlılıkları incelendiğinde tüm hisse senetlerinin beta değerlerinin pozitif olduğu görülmektedir. Buna incelenen hisse senetleri BIST 100 endeksi ile aynı yönde hareket etmektedir. En düşük riskli hisse senedinin ADESE A.Ş. hisse senedi, en yüksek riske sahip hisse senedinin ise MAVİ A.Ş. hisse senedi olduğu tespit edilmiştir.

Geçmiş dönemlerde hisse senetlerinin sağladığı aylık ortalama getiri ile aylık risksiz getiri kıyaslandı̆̆ında yalnızca dört hisse senedinin risksiz getirinin üzerinde kazanç sağladığı görülmektedir. Diğer hisse senetlerinden dördü ise risksiz getirinin altında getiri sağlamış, üç hisse senedi ise yatırımcılarına aylık ortalamada zarar ettirmiştir.

Treynor oranı ile hisse senetlerinin performansı ölçüldüğünde en iyi performansı gösteren hisse senedinin Vakko A.Ş. hisse senedi, en kötü performansı gösterenin ise Teknosa A.Ş. hisse senedi olduğu görülmektedir. Bununla birlikte yalnızca Vakko, Adese, Milpa ve Bim hisse senetlerinin pozitif Treynor oranına sahip olduğu tespit edilmiştir. Pozitif Treynor oran hisse senedinin risksiz getirinin üzerinde getiri sağladığını göstermektedir. Diğer hisse senetlerinin Treynor oranı ise negatif çıkmış, hisse senetleri risksiz getirinin altında getiri sağlamışlardır.

Geçmiş veriler üzerinden yapılan değerlendirmelerden elde edilen sonuçlar BIST 100 endeksinin yükseldiği Eylül ayı ve endeksin düştüğü Ekim ayı gerçekleşen getirileri ile karşılaştırılmıştır. Eylül ayında en yüksek getiriyi Adese hisse senedinin sağladığı, söz konusu hisse senedinin Treynor performans ölçümünde ikinci sırada olduğu, risk açısından ise en düşük riskli hisse senedi olduğu görülmektedir. Ekim ayında en yüksek getiriyi ise Mepet hisse senedi sağlamıştır. Söz konusu hisse senedi Treynor oranında en kötü performansa sahip üçüncü, en yüksek riskli ikinci hisse senedidir. Bununla birlikte Ekim ayı BIST 100 endeksinin düştüğü bir dönem olmuştur. Eylül ve Ekim ayı toplam getirilerine bakıldığında en iyi performansı da Mepet hisse senedinin, ardından da Adese hisse senedinin gösterdiği görülmektedir.

Son olarak pozitif Treynor oranına sahip hisse senetlerine eşit oranlarda yatırım yapmıs bir yatırımcı ile negatif Treynor oranına sahip hisse senetlerine eşit oranlarda yatırım yapmış bir yatırımcının Eylül ve Ekim ayı toplam getirileri kıyaslanmıştır. Buna göre pozitif Treynor oranlı hisse senetleri Eylül ayında \%21,09 kar elde etmiş, Ekim ayında ise \% 2,95 zarar etmiştir. 
Yatırımcının aylık ortalama karı \%9,07 olmuştur. Negatif Treynor oranlı hisse senetlerine yatırım yapan yatırımcı ise Eylül ayında \%15,14 kar elde etmiş, Ekim ayında ise \%1,05 zarar etmiştir. Yatırımcının aylık ortalama karı \%7,04 olmuştur. Buna göre riske göre elde edilecek getiriyi esas alan Treynor oranı yüksek olan hisse senetlerine yatırım yapan yatırımcı, Treynor oranı düşük (negatif) olan hisse senetlerine yatırım yapan yatırımclardan daha yüksek aylık ortalama getiri elde etmiştir.

Çalışmamızda hisse senetlerinin geçmiş getirileri üzerinden performans ölçümü 5 yıllık veriler üzerinden yapılmış olup, borsada işlem görmeye sonradan başlamış iki şirket hisseleri için söz konusu ölçüm dönemi daha kısa olmuştur. Bahsedilen husus tarafımızca araştırmanın önemli kısıtları arasında görülmektedir. Ayrıca çalışmada 5 yıllık dönem içerisinde performans ölçümü aylık getiriler üzerinden yapılmıştır. Gelecek çalışmalarda getiri dönemlerinin haftalık veya günlük olarak daraltılarak daha detaylı performans ölçümlerinin gerçekleştirilebileceği tarafımızca tavsiye edilmektedir.

Çalışmamız yalnızca hisse senetlerinin performans ölçümü ile ilgili olup, yatırım tavsiyesi niteliği taşımamaktadır. Yapılan yatırımın risk içermesi nedeniyle, hisse senedi yatırımcılarının, risksiz piyasa getirisinin üzerinde getiri elde edecek hisse senetlerini tercih etmek için profesyonel yatırım danışmanlarından destek almaları yararlı olacaktır.

\section{KAYNAKÇA}

Aksoy, A. ve Tanrı̈ven, C. (2007). Sermaye Piyasası Yatırım Araçları ve Analizi. Ankara: Gazi.

Alkan, U. ve Kuşaksızoğlu, B. (2017). Türkiye'de Yatırım Fonlarının Getiriye Dayalı Performans Değerlemesi. Kesit Akademi Dergisi, (11), 297-320.

Alptekın, N. (2009). Performance Evaluation of Turkish Type A Mutual Funds and Pension Stock Funds by Using Topsis Method. International Journal of Economics and Finance Studies, 1 (2), $11-22$.

Arslan, S. ve Çelik, M. (2018). Türkiye'deki Emeklilik Yatırım Fonlarının Performanslarının BIST100 Endeksinin Performansı ile Karşılaştırılması. İşletme ve İktisat Çalışmaları Dergisi, 6 (4), 61-73.

Ayaydın, Y. (2013). Türkiye'deki Emeklilik Yatırım Fonlarının Performanslarının Analizi. Çukurova Üniversitesi Sosyal Bilimler Enstitüsü Dergisi, 22 (2), 59-80.

Ceylan, A. ve Korkmaz, T. (2008). Borsada Uygulamalı Portföy Yönetimi. Bursa: Ekin.

Çalışkan, T. (2011). Black-Litterman ve Markowıtz Ortalama Varyans Modeliyle Oluşturulan Portföylerin Performanslarının Ölçülmesi. Yönetim ve Ekonomi Araştırmaları Dergisi, 9 (15), 99-109.

Dağlı, H., Bank, S. ve Er, B. (2008). Türkiye' deki Bireysel Emeklilik Yatırım Fonlarının Performans Değerlendirmesi. Muhasebe ve Finansman Dergisi, (40), 84-95.

Demir, S. ve Kaderli, Y. (2007). Beta Katsayılarının İstikrarı: İstanbul Menkul Kıymetler Borsası'nda Bir Uygulama. Muhasebe ve Finansman Dergisi, (35), 185-197.

Güçlü, F. (2019). Katılım 30 Endeksinin Zamanla Değişen Betası. Uluslararası İktisadi ve İdari İncelemeler Dergisi, (BOR Özel Sayısı), 115-126. 
İpekten, N., İpekten, G. ve Elmas, B. (2020). Türkiye'de A Tipi Yatırım Fonlarının Performans Analizi (01/2013- 12/2017). Ömer Halisdemir Üniversitesi İktisadi ve İdari Bilimler Fakültesi Dergisi, 13 (3), 462-476.

İskenderoğlu, Ö. (2012). Beta Katsayılarının Tahmini: İstanbul Menkul Kıymetler Borsası Üzerine Bir Uygulama. Ege Akademik Bakış 12(1). 67-76.

Kök, D. ve Erikçi, M. (2015). Türkiye'de A Tipi Yatırım Fonlarının Performansı: 2004-2013 Dönemi Analizi. Pamukkale İşletme ve Bilişim Yönetimi Dergisi, (2), 15-26.

Oran, J., Avci, E., Ashoor, M. and Tan, O. (2017). An Evaluation of Turkish Mutual and Pension Funds' Performances. Press Academia Procedia, 3 (1), 131-142.

Özer, A. ve Çömlekçi, İ. (2020). Odaklanma Stratejisi ve Çeşitlendirme Stratejisi İzleyen Fonların Performanslarının Karşılaştırılması. Elektronik Sosyal Bilimler Dergisi, 19 (76), 2012-2023.

Samırkaş, Ö. ve Düzakın, D. (2012). Türkiye'deki A ve B Tipi Yatırım Fonlarının Performans Analizi. Çukurova Üniversitesi Sosyal Bilimler Enstitüsü Dergisi, 21 (3), 391-410.

Sarılı, S. and Çakmur Yıldırtan, Z. (2016). Comparative Analysis of Key Performance Indicators of Islamic Index. Marmara Üniversitesi İktisadi ve İdari Bilimler Dergisi, 38 (2), 273-291.

Sevinç, D. ve Yakar, A. (2019). Türkiye'deki Pay Senedi Yatırım Fonlarının Performans Analizi. Anadolu Üniversitesi İktisadi ve İdari Bilimler Fakültesi Dergisi, 20 (2), 112-129.

Sönmezler, G. (2021). Covid-19 Pandemi Sürecinin BİST-30 Hisse Senetlerine Etkilerinin Karışıklık Matrisi ile Analizi. Maliye ve Finans Yazıları, Özel Sayı (2), 51-70 .

Tetik, N. ve Uğur, A. (2011). Beta Katsayısının Tahmininde Getiri Aralığının Sektörler İtibariyle Analizi: İmkb’de Bir Araştırma. Atatürk Üniversitesi İktisadi ve İdari Bilimler Dergisi, 24 (1), $15-24$

Uysal, M. and Adal1, Z. (2018). Performance Measurement of Pension Investment Funds in Turkey: Comparing Performance of Traditional and Islamic Pension Investment Funds. Fiscaoeconomia, 2 (2), 50-73. 